\title{
Stability of TOL plasmid pWW0 in Pseudomonas putida mt-2 under non-selective conditions in continuous culture
}

\author{
Wouter A. Duetz* and Johan G. van ANDel \\ Laboratory for Waste Materials and Emissions, National Institute of Public Health and Environmental Protection, \\ PO Box 1, 3720 BA Bilthoven. The Netherlands
}

(Received 1 November 1990; revised 20 February 1991; accepted 27 February 1991)

\begin{abstract}
Pseudomonas putida mt-2, harbouring the TOL plasmid pWW0, was grown in chemostat culture under succinate-, sulphate-, ammonium- or phosphate-limitation at different dilution rates. The fraction of mutant cells lacking the plasmid-encoded enzymes for the degradation of toluene and xylene (TOL- cells), was determined. Genetic analysis revealed that all $\mathrm{TOL}^{-}$cells isolated harboured partially deleted plasmids, lacking the TOL catabolic genes. The growth-rate advantage of the $\mathrm{TOL}^{-}$cells was quantified from the kinetics of their increase as a fraction of the total population. At a dilution rate of $0 \cdot 1 \mathrm{~h}^{-1}$ no growth-rate advantage of $\mathrm{TOL}^{-}$cells was found when phosphate or ammonium were limiting. Under sulphate-limitation, ingrowth of $\mathrm{TOL}^{-}$cells was evident but did not follow a straightforward pattern. Under succinate-limitation the growth-rate advantage was the highest, particularly at low dilution rates (about $50 \%$ at $D=0.05 \mathrm{~h}^{-1}$ ). In phauxostat culture, at the maximal growth rate, the growth-rate advantage of $\mathrm{TOL}^{-}$cells was less than $1 \%$. The specific activity in $\mathrm{TOL}^{+}$cells of the plasmidencoded enzyme catechol 2,3-dioxygenase was relatively high at a low growth rate.
\end{abstract}

\section{Introduction}

Many bacterial strains, particularly those of the genus Pseudomonas, are capable of degrading xenobiotic compounds; the catabolic enzymes involved are often encoded on large plasmids. These so-called catabolic plasmids (for a review see Sayler et al., 1990) provide their hosts with the advantage of a broader growthsubstrate spectrum. To be competitive in a certain niche, however, the advantage must be big enough to compensate for the costs of maintenance and expression of the catabolic plasmid. These considerations may be important for proliferation of strâns harbouring catabolic plasmids and may explain why certain xenobiotics persist in biological systems even though their biodegradability has been proven possible.

To obtain more insight on the burden which the maintenance and expression of a plasmid may impose on the host cell, a frequently used method is to monitor the persistence of the plasmid-harbouring strain in continuous culture conditions. Most work has been done with strains harbouring plasmids encoding antibiotic resistance (e.g. Melling et al., 1977; Godwin \& Slater, 1979; Wouters et al., 1980). Also, the persistence of genetically engineered plasmids has been subject to considerable research in recent years (e.g. Seo \& Bailey, 1985; Bentley et al., 1990).

Most studies done on the stability of catabolic plasmids were concerned mainly with growth on benzoate (e.g. Keshavarz et al., 1985; Williams et al., 1988; Stephens \& Dalton, 1988). The strong selection against TOL-plasmid harbouring cells observed during growth on benzoate is caused, however, by differences in the degradation pathway between the wild-type strain and mutant cells.

In this study we determined the stability of the lowcopy-number TOL plasmid pWW0 $(117 \mathrm{~kb})$ in Pseudomonas putida $\mathrm{mt}-2$ under non-selective conditions (succinate as the carbon and energy source) in continuous culture at different limitations and dilution rates. Two experimental approaches were employed. Firstly, in persistence experiments, succinate was fed to a continuous culture containing $100 \%$ TOL-plasmid-bearing cells; the kinetics of ingrowth of spontaneous mutant cells that lack the plasmid-encoded enzymes ( $\mathrm{TOL}^{-}$cells) were then examined. Secondly, the growth-rate advantage of these $\mathrm{TOL}^{-}$cells was further quantified in competition experiments after seeding them into a culture of wild-type cells. 


\section{Methods}

Nomenclature. The nomenclature and symbols used in this paper are the same as in the preceding paper (Duetz et al., 1991); in addition, $C$ is the ratio of the growth rates of the $\mathrm{TOL}^{+}$and $\mathrm{TOL}^{-}$populations and $t_{95 \%}$ is defined as the time at which the percentage of $\mathrm{TOL}^{+}$cells falls below $95 \%$.

Bacterial strain. Pseudomonas putida mt-2 (ATCC 33015) harbouring the TOL plasmid $\mathrm{pWW0}$ was a gift of $\mathrm{P}$. A. Williams (Bangor, UK). It was maintained in agar tubes on a mineral medium with $m$-toluate as the sole carbon and energy source $\left(\mathrm{C}\right.$-source) at $4{ }^{\circ} \mathrm{C}$. $\mathrm{TOL}^{-}$strains were maintained in the same way but with succinate as the sole $\mathrm{C}$-source.

Media. The growth medium was a mineral salts solution according to Evans et al. (1970), except that the concentrations of all nutrients were decreased to $25 \%$ of the published concentration, supplemented with $5 \mathrm{~mm}$ - $m$-toluate, $5 \mathrm{mM}$ - $m$-methylbenzyl alcohol or $10 \mathrm{~mm}$-succinate, when carbon-limited, or twice those concentrations for other nutrient limitations. For ammonium-limitation the $\mathrm{NH}_{4} \mathrm{Cl}$ concentration was $1.88 \mathrm{mM}$, for phosphate-limitation the $\mathrm{NaH}_{2} \mathrm{PO}_{4}$ concentration was $150 \mu \mathrm{M}$, and for sulphate-limitation the $\mathrm{Na}_{2} \mathrm{SO}_{4}$ concentration was $30 \mu \mathrm{M}$. For all limitations the optical density at $540 \mathrm{~nm}$ was approximately 0.7 (dry wt approx. $400 \mathrm{mg} \mathrm{l}^{-1}$ ) at a dilution rate of $0 \cdot 1 \mathrm{~h}^{-1}$. Nitrilotriacetate (NTA) was used as a chelating agent. Except for phosphate limitation, the $\mathrm{pH}$ of chemostat cultures was maintained at 7.0 using media containing $50 \mathrm{~mm}-\mathrm{KH}_{2} \mathrm{PO}_{4} / \mathrm{K}_{2} \mathrm{HPO}_{4}$ buffer, silicone antifoaming agent (BDH) was added to the growth medium at a concentration of $62 \mu \mathrm{l}^{-1}$. The medium for growth in pHauxostat culture was identical but contained $15 \mathrm{~mm}$-succinate and had a $\mathrm{pH}$ of $6 \cdot 4$.

Continuous culture. For chemostat culture at the lowest dilution rate $\left(D=0.05 \mathrm{~h}^{-1}\right)$ and under phosphate-limitation $500 \mathrm{ml}$ fermenters $(500$ series, L \& H Engineering) were used. The culture was stirred at 1500 r.p.m. The pH was maintained at $7.0 \pm 0.05$ by automatic addition of $\mathrm{NaOH}(1.0 \mathrm{M})$. The temperature was maintained at $28 \pm 1{ }^{\circ} \mathrm{C}$.

All other chemostat experiments were done in $100 \mathrm{ml}$ glass fermenters, shaped like an Erlenmeyer flask, with a small headspace volume and stirred magnetically at 550 r.p.m. Medium entered at the bottom of the vessel through a needle with an internal diameter of $1.0 \mathrm{~mm}$. Air was supplied through the same needle at $100 \mathrm{ml} \mathrm{min}^{-1}$. The fermenter was equipped with two stainless steel baffles and was kept at $28^{\circ} \mathrm{C}$.

$P$. putida mt-2 was grown on succinate at a non-limiting rate by making use of a phauxostat as described in the preceding paper (Duetz et al., 1991). Whenever wall growth was observed, the complete cell suspension was transferred to a new sterile fermenter vessel of the same type, without interrupting the addition of medium for more than $1 \mathrm{~min}$.

Competition experiments. Competition experiments were done in the following way. A TOL-bearing strain and a derivative with a partially deleted plasmid were grown separately in two $500 \mathrm{ml}$ chemostats with succinate as the sole C-source, at a dilution rate of $0.5 \mathrm{~h}^{-1}$. After $2 \mathrm{~d}$, when both chemostats were assumed to have reached a steady state, a $100 \mathrm{ml}$ chemostat was inoculated with a $90 \mathrm{ml}$ sample from the chemostat with the $\mathrm{TOL}^{+}$strain and a $10 \mathrm{ml}$ sample from the chemostat with the $\mathrm{TOL}^{-}$strain. The dilution rate of this $100 \mathrm{ml}$ chemostat was set at $0.5 \mathrm{~h}^{-1}$ while the dilution rates of the two mother cultures were lowered to $0 \cdot 2 \mathrm{~h}^{-1}$. After a further $2 \mathrm{~d}$, a second $100 \mathrm{ml}$ chemostat $\left(D=0.2 \mathrm{~h}^{-1}\right)$ was inoculated in the same way and so on for dilution rates of 0.1 and $0.05 \mathrm{~h}^{-1}$.

Assays. Assays for cell density, the percentage of $\mathrm{TOL}^{+}$cells in a population, the statistical calculation of $95 \%$ reliability intervals and the genetic characterization of $\mathrm{TOL}^{-}$cells were done as described in the preceding paper (Duetz et al., 1991).
Assay for catechol 2,3-dioxygenase. Extracts of culture cells sampled from the chemostats were prepared by sonication and centrifugation. Subsequently, catechol 2,3-dioxygenase activity was determined according to the method of Sala-Trepat \& Evans (1971).

Quantification from population dynamics of the growth-rate advantage of $\mathrm{TOL}^{-}$cells. Consider the competition between two strains $\mathrm{A}$ and $\mathrm{B}$, present at population fractions $p_{\mathrm{A}}$ and $p_{\mathrm{B}}$, and with growth rates $\mu_{\mathrm{A}}$ and $\mu_{\mathrm{B}}$. In chemostat culture, the dilution rate $D$ is an externally set parameter and $\mu_{\mathrm{A}}$ and $\mu_{\mathrm{B}}$ are variables. When it is assumed that the ratio of $\mu_{\mathrm{A}}$ and $\mu_{\mathrm{B}}$ is constant $\left(\mu_{\mathrm{B}} / \mu_{\mathrm{A}}=C\right)$, substitution of equation (3) in equation (1) (both equations can be found in the preceding paper: Duetz et al., 1991) yields

$$
\left(\frac{\mathrm{d} p_{\mathrm{A}}}{\mathrm{d} t}\right)=\frac{D p_{\mathrm{A}}\left(1-p_{\mathrm{A}}\right)}{(C / 1-C)+p_{\mathrm{A}}}
$$

Integration with the boundary condition $p_{\mathrm{A}}(t=0)=p_{\mathrm{A}}^{0}$ yields

$$
\frac{\left(p_{\mathrm{A}}\right)^{C}}{1-p_{\mathrm{A}}}=\frac{\left(p_{\mathrm{A}}^{0}\right)^{C}}{1-p_{\mathrm{A}}^{0}} e^{(1-c) D t}
$$

Equation (2) can be used to describe the competition in chemostat culture between a fraction of $\mathrm{TOL}^{+}$cells $\left(p_{+}\right)$and a fraction of $\mathrm{TOL}^{-}$ cells $\left(p_{-}\right)$, with a constant growth-rate ratio $\mathrm{C}=\mu_{+} / \mu_{-}$and an initial fraction of the $\mathrm{TOL}^{-}$population of $p_{-}^{0}$.

$$
\frac{\left(p_{-}\right)^{C}}{1-p_{-}}=\frac{\left(p_{-}^{0}\right)^{C}}{1-p_{-}^{0}} e^{(1-C) D r}
$$

Values for $C$ and $p_{-}^{0}$ were generated by non-linear least-square fitting of equation (3) to the experimental data for the change of $p_{-}$in time, making use of a subroutine written in FORTRAN (available from the authors). In the fitting procedure the datapoints were weighted equally but datapoints with values for $p_{-}$of $<3 \%$ and $>97 \%$ were ignored. The value for $p_{-}^{0}$ is arbitrary since the contribution of segregation in the initial phase is not taken into account.

For persistence experiments in phauxostat culture a value for $C$ was calculated from the value for the growth rates of the $\mathrm{TOL}^{+}$and $\mathrm{TOL}^{-}$ cells as determined according to the preceding paper (Duetz et al., 1991).

Estimation of segregation rate. If it is assumed that the first appearing TOL $^{-}$cells do not have a growth-rate advantage, the segregation rate $R$ can be estimated by

$$
\left(\frac{\mathrm{d} p_{-}}{\mathrm{d} t}\right)=R
$$

Integration with the boundary condition that $p_{-}(t=0)=0$ yields

$$
R=\frac{p_{-}(t)}{t}
$$

For calculating $R$ in this way we used the first data point of the persistence experiment with a fraction $p_{-}$that was significantly over $1 \%$. The assumption of the absence of a growth-rate advantage of the mutant cells and the assumption that $p_{-}^{0}=0$ both lead to an overestimation of $R$. Accordingly, we present the resulting values for $R$ as maximal values.

\section{Results}

\section{Effects of growth-limiting nutrient on plasmid maintenance}

$P$. putida $\mathrm{mt}-2$ was grown in continuous culture in a mineral medium at a fixed dilution rate of $0.1 \mathrm{~h}^{-1}$. During the first $5 \mathrm{~d}$ after inoculation the sole $\mathrm{C}$-source was $m$-toluate. In this period, a steady state of $100 \%$ 


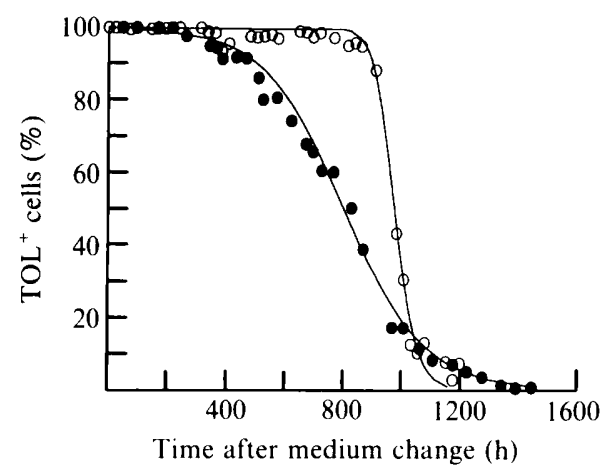

Fig. 1

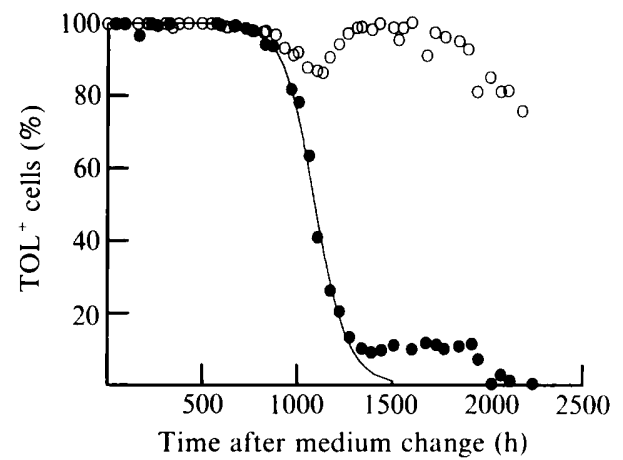

Fig. 2

Fig. 1. Persistence of pWW0 in $P$. putida $\mathrm{mt}-2$ grown in chemostat culture under succinate-limitation at a dilution rate of $0 \cdot 1 \mathrm{~h}^{-1} . \bullet, \bigcirc$, Fractions $p_{+}$in two duplicate experiments; generating values for the growth-rate ratio $C$ of 0.94 and 0.76 respectively.

Fig. 2. Persistence of pWW0 in P. putida mt-2 grown in chemostat culture under sulphate-limitation at a dilution rate of $0 \cdot 1 \mathbf{h}^{-1} . O^{\circ}, \mathrm{O}$, Fractions $p_{+}$in two duplicate experiments; _ generating a value for the growth-rate ratio $C$ of 0.89 . For the duplicate experiment no value for $C$ could be calculated.

$\mathrm{TOL}^{+}$cells was established under phosphate-, sulphateor carbon- and energy-limitation, but not under ammonium-limitation, where almost immediately a fraction (up to $80 \%$ ) of $\mathrm{TOL}^{-}$cells appeared. To establish a $100 \%$ $\mathrm{TOL}^{+}$population under ammonium-limiting conditions, $m$-methylbenzyl alcohol was used as a C-source instead of $m$-toluate. After this initial stage, the medium containing $m$-toluate or $m$-methylbenzyl alcohol was replaced by a medium with succinate as the sole $\mathrm{C}$ source. The time to reach a $\mathrm{TOL}^{+}$population of $95 \%$ or less $\left(t_{95 \%}\right)$ was determined. Subsequently, the ratio $(C)$ of the growth rates of $\mathrm{TOL}^{+}$cells and $\mathrm{TOL}^{-}$cells was calculated by fitting equation (3) to the data points.

Under phosphate- or ammonium-limitation the $\mathrm{TOL}^{+}$ cells persisted for a period of more than $2000 \mathrm{~h}(200$ vessel volume changes). The fraction of the $\mathrm{TOL}^{-}$ population never exceeded $3 \%$ of the whole population.

Two replicate experiments done under carbon- and energy-limitation both showed a complete loss of the $\mathrm{TOL}^{+}$population within $1500 \mathrm{~h}$ (see Fig. 1). However, the $t_{95 \%}$ times ( 400 and $950 \mathrm{~h}$ ) and the calculated growthrate ratios $(C=0.94$ and 0.76$)$ were dissimilar.

The ingrowth of $\mathrm{TOL}^{-}$cells observed under sulphatelimitation (Fig. 2) did not follow the same distinct pattern as under carbon- and energy-limitation. The $t_{95} \%$ times in the replicates were about the same (830 and $980 \mathrm{~h}$ ), but in the first experiment the subsequent further decrease in the percentage of $\mathrm{TOL}^{+}$cells ceased at a level of about $10 \%$ (until then $C=0.89$ ). The other experiment even showed a significant increase in the $\mathrm{TOL}^{+}$ population after the initial decrease to $85 \% \mathrm{TOL}^{+}$cells.

These results show that the type of nutrient limitation has a pronounced effect on the persistence of the $\mathrm{TOL}^{+}$ population. Because carbon- and energy-limitation al- ways appeared to result in a ready and uncomplicated ingrowth of a $\mathrm{TOL}^{-}$population, we determined the influence of the dilution rate on the persistence of $\mathrm{TOL}^{+}$ cells under this limitation.

\section{Effect of growth rate on the persistence of $\mathrm{TOL}^{+}$cells}

The persistence of $\mathrm{TOL}^{+}$cells was examined under carbon- and energy-limiting conditions with different dilution rates in the way described above. At the highest dilution rate tested $\left(0.5 \mathrm{~h}^{-1}\right)$ the $\mathrm{TOL}^{+}$population was extremely persistent (see Fig. 3). The percentage of TOL $^{-}$cells was more than twice the growth rate of the $\mathrm{TOL}^{+}$cells $(C=0.38)$. Table 1 shows that at intermediate dilution rates $\left(0 \cdot 1\right.$ and $\left.0 \cdot 2 \mathrm{~h}^{-1}\right)$ the values for dilution rate tested $\left(0.05 \mathrm{~h}^{-1}\right)$ the $t_{95 \%}$ was reached almost immediately when the medium was switched from $m$-toluate to succinate and the growth rate of the $\mathrm{TOL}^{-}$cells was more then twice the growth rate of the $\mathrm{TOL}^{+}$cells $(C=0 \cdot 38)$. Table 1 shows that at intermediate dilution rates $\left(0 \cdot 1\right.$ and $\left.0 \cdot 2 \mathrm{~h}^{-1}\right)$ the values for $t_{95 \%}$ and $C$ were intermediate between these two extremes (see also Fig. 3).

In addition to persistence experiments under carbonand energy-limitation, $P$. putida $\mathrm{mt}-2$ harbouring $\mathrm{pWW} 0$ was grown in phauxostat culture, which allows continuous cultivation at non-limited growth rates $\left(D=1.04 \pm 0.05 \mathrm{~h}^{-1}\right.$ in this case). The residual concentration of succinate was about $4 \mathrm{~mm}$. The $t_{95 \%}$ was $400 \mathrm{~h}$ (about 420 vessel volume changes). The ingrowth of TOL $^{-}$cells ceased at about $15 \%$. The growth-rate ratio $C$ until then was $>0.99$ (see Fig. 4 and Table 1). 




Fig. 3

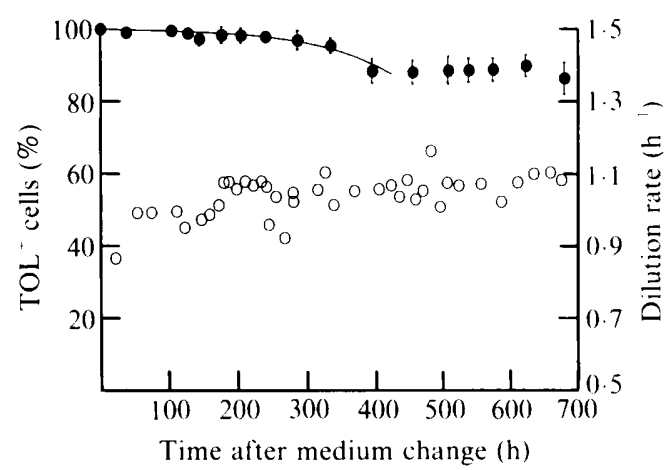

Fig. 4

Fig. 3. Persistence of pWW0 in $P$. putida $\mathrm{mt}-2$ grown in chemostat culture under succinate-limitation at different dilution rates. Fractions $p_{+}$at dilution rates of $0.5(\bullet), 0 \cdot 2(O), 0 \cdot 1(\mathbb{G})$ and $0.05(\square)$ are shown. - , Best-fit curves of equation (3) (see Methods) to the experimental values for $p_{+}$, generating values for the growth-rate ratio $C$ of $0.995,0.965,0.94$ and 0.38 respectively.

Fig. 4. Persistence of pWW0 in $P$. putida $\mathrm{mt}-2$ grown at a non-limited rate on succinate in phauxostat culture. Fraction $p_{+}$, (error bars indicate $95 \%$ reliability intervals); $\bigcirc$, dilution rate $\left(\mathrm{h}^{-1}\right) ;-$, best-fit curve of equation (3) (see preceding paper: Duetz et al., 1991 ) to the experimental values for $p_{+}$, generating a value for the growth-rate difference $v$ of $0.01 \mathrm{~h}^{-1}$ (corresponding to a growth-rate ratio $C$ of 0.99 ).

Table 1. Effect of dilution rate on catechol 2,3-dioxygenase activity, the moment at which the fraction of $\mathrm{TOL}^{+}$cells drops below $95 \%\left(t_{95 \%}\right)$ and the ratio $(C)$ of the growth rate of $\mathrm{TOL}^{+}$and $\mathrm{TOL}^{-}$cells as measured during persistence or competition experiments

\begin{tabular}{|c|c|c|c|c|c|}
\hline \multirow{2}{*}{$\begin{array}{l}\text { Dilution } \\
\text { rate } \\
\left(\mathrm{h}^{-1}\right)\end{array}$} & \multirow{2}{*}{$\begin{array}{c}\text { Type of } \\
\text { experiment }\end{array}$} & \multirow{2}{*}{$\begin{array}{c}\text { Catechol } \\
\text { 2,3-dioxygenase } \\
\text { activity } \\
{\left[\mathrm{mU}(\mathrm{mg} \text { protein })^{-1}\right]}\end{array}$} & \multicolumn{2}{|c|}{$t_{95 \%}$} & \multirow{2}{*}{$\begin{array}{c}C \\
\left(=\mu_{+} / \mu_{-}\right)\end{array}$} \\
\hline & & & $\mathrm{h}$ & changes & \\
\hline $\begin{array}{l}1 \cdot 04 \\
\left(\mu_{\max }\right)\end{array}$ & $\begin{array}{l}\text { Persistence } \\
\text { Competition }\end{array}$ & $\begin{array}{l}\text { ND } \\
\text { ND }\end{array}$ & 390 & 400 & $\begin{array}{r}>0.99 \\
0.99 \dagger\end{array}$ \\
\hline 0.5 & $\begin{array}{l}\text { Persistence, exp. I } \\
\text { Persistence, exp. II } \\
\text { Competition }\end{array}$ & $\begin{array}{c}116 \pm 15 \\
\mathrm{ND} \\
\mathrm{ND}\end{array}$ & $\begin{array}{r}1240 \\
> \\
1150\end{array}$ & $\begin{array}{r}620 \\
>575\end{array}$ & $\begin{array}{r}0.995 \\
>0.94\end{array}$ \\
\hline $0 \cdot 2$ & $\begin{array}{l}\text { Persistence, exp. I } \\
\text { Persistence, exp. II } \\
\text { Competition }\end{array}$ & $\begin{array}{c}336 \pm 38 \\
\mathrm{ND} \\
\mathrm{ND}\end{array}$ & $\begin{array}{l}820 \\
480\end{array}$ & $\begin{array}{r}164 \\
96\end{array}$ & $\begin{aligned} & 0.965 \\
& 0.982 \\
> & 0.96\end{aligned}$ \\
\hline $0 \cdot 1$ & $\begin{array}{l}\text { Persistence, exp. I } \\
\text { Persistence, exp. II } \\
\text { Competition }\end{array}$ & $\begin{array}{l}492 \pm 2 \\
\text { ND } \\
\text { ND }\end{array}$ & $\begin{array}{l}950 \\
400\end{array}$ & $\begin{array}{l}95 \\
40\end{array}$ & $\begin{array}{l}0 \cdot 76 \\
0 \cdot 94 \\
0 \cdot 82\end{array}$ \\
\hline 0.05 & $\begin{array}{l}\text { Persistence } \\
\text { Competition }\end{array}$ & $\begin{array}{c}1131^{*} \\
\mathrm{ND}\end{array}$ & 0 & 0 & $\begin{array}{l}0 \cdot 38 \\
0 \cdot 60\end{array}$ \\
\hline
\end{tabular}

ND, Not determined.

* Single measurement

$\dagger$ Result from a competition experiment in sequential batch culture.

\section{Competition experiments}

Persistence experiments showed that the value of the growth-rate ratio $C$ was strongly dependent on the dilution rate. We wanted to establish if this effect of the dilution rate is not due to the selection of different $\mathrm{TOL}^{-}$ genotypes. We therefore isolated a $\mathrm{TOL}^{-}$strain (carrying a partially deleted plasmid) and a $\mathrm{TOL}^{+}$strain simultaneously from the same persistence experiment $\left(D=0 \cdot 2 \mathrm{~h}^{-1}\right)$. Subsequently, we did competition experiments with this set of strains at different dilution rates.
The ingrowth of an initial population of $10 \% \mathrm{TOL}^{-}$cells was monitored and analysed mathematically. The influence of the dilution rate on the growth-rate ratio $C$ was similar to that found during the persistence experiments (see Table 1). Fig. 5 shows the result of the competition experiment at a dilution rate of $0.05 \mathrm{~h}^{-1}$.

\section{Catechol 2,3-dioxygenase activities}

The activity of catechol 2,3-dioxygenase was determined during the stage in persistence experiments when the 




Fig. 5. Competition between $\mathrm{TOL}^{-}$and $\mathrm{TOL}^{+}$cells in chemostat culture when grown on succinate under succinate-limitation at a dilution rate of $0.05 \mathrm{~h}^{-1}$. equation (3) (see Methods) to the experimental values for $p_{+}$, generating a value for the growth-rate ratio $C$ of 0.38 .

culture was already adapted to succinate as the sole Csource, but did not yet contain a significant fraction of $\mathrm{TOL}^{-}$cells (see Table 1). At the lowest dilution rate tested $\left(D=0.05 \mathrm{~h}^{-1}\right)$ the catechol 2,3-dioxygenase activity was about 10 times higher that at $D=0.5 \mathrm{~h}^{-1}$. In separate experiments the activity remained constant but decreased parallel to the percentage of $\mathrm{TOL}^{+}$cells.

\section{Segregation rates}

We calculated (maximal) segregation rates $R$ from the results from the persistence experiments. Values for $R$ ranged from $6.2 \times 10^{-5}$ to $1.0 \times 10^{-4} \mathrm{~h}^{-1}$. No correlation with the type of limitation or dilution rate could be found. These values for $R$ are too low to influence the competition pattern significantly when the fraction of TOL $^{-}$cells is more than $2 \%$ and the value for $C$ is less than about 0.95 .

\section{Genetic characterization of $\mathrm{TOL}^{-}$mutants}

From all persistence experiments one or more $\mathrm{TOL}^{-}$ mutants were isolated. All $\mathrm{TOL}^{-}$mutants appeared to harbour plasmids of $78 \mathrm{~kb}$. HindIII restriction patterns

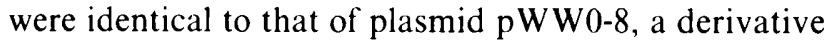
of pWW0 lacking all TOL catabolic genes and described previously by Meulien et al. (1981).

\section{Discussion}

The purpose of this study was to examine the behaviour of $P$. putida $\mathrm{mt}-2$ harbouring TOL plasmid $\mathrm{pWW} 0$ under conditions where the plasmid-encoded catabolic capacity was unnecessary. The influence of the limiting nutrient was determined at a dilution rate of $0.1 \mathrm{~h}^{-1}$ with succinate as the sole $\mathrm{C}$-source.

High persistence of the wild-type strain was found under phosphate- or ammonium-limitation with succin- ate as a $\mathrm{C}$-source. The observation that small populations of $\mathrm{TOL}^{-}$cells (up to $3 \%$ of the whole population) evolved without further ingrowth indicates that the growth-rate advantage of $\mathrm{TOL}^{-}$cells is very small under these conditions. The finding that $\mathrm{TOL}^{+}$plasmid-containing cells are very persistent under phosphate-limiting conditions is the most pronounced difference with similar studies undertaken with other plasmids. For plasmids encoding antibiotic resistance (R-plasmids) like TP120 (Godwin \& Slater, 1979) and pBR322 (Wouters et al., 1980), phosphate-limiting conditions appear to select strongly for cells lacking the resistance genes. In these studies counterselection for the wild-type strain was less strong under carbon- and energy-limitation. This is in contrast to the poor persistence of our catabolic plasmid under carbon- and energy-limitation.

The low persistence of the wild-type strain under sulphate limitation compared to phosphate- and ammonium-limitation is also different from results found with R-plasmids. Chew et al. (1988) reported a relatively high persistence of plasmid pAT153 (a derivative of pBR322) under sulphate-limitation.

The fast ingrowth of $\mathrm{TOL}^{-}$cells under ammoniumlimitation with $m$-toluate as the sole $\mathrm{C}$-source is difficult to explain since $\mathrm{TOL}^{-}$cells cannot metabolize $m$-toluate. Cell debris and excretion products of $\mathrm{TOL}^{+}$cells probably support growth of the $\mathrm{TOL}^{-}$population. This phenomenon may possibly be related to the inhibitory effect of benzoate on $\mathrm{TOL}^{+}$cells described in the preceding paper (Duetz et al., 1991).

A strong influence of dilution rate on persistence was found under carbon- and energy-limitation. At the lowest dilution rate tested $\left(D=0.05 \mathrm{~h}^{-1}\right) \mathrm{TOL}^{-}$cells grew about twice as fast as $\mathrm{TOL}^{+}$cells. At a dilution rate of $0.5 \mathrm{~h}^{-1}$, or at a non-limited rate in phauxostat culture, $\mathrm{TOL}^{-}$ cells exhibited almost no growth-rate advantage $(<1 \%)$. A similar dependence on dilution rate was found during competition experiments (see Table 1) when the same isolated $\mathrm{TOL}^{-}$strain and $\mathrm{TOL}^{+}$strain were used for each dilution rate. This rules out the possibility that the influence of the dilution rate found during the persistence experiments was caused solely by different $\mathrm{TOL}^{-}$ genotypes evolving. The higher growth-rate advantage of segregants at low dilution rate is in agreement with the studies on R-plasmids mentioned above.

Under carbon- and energy-limitation a relationship seems to exist between the high growth-rate advantage of $\mathrm{TOL}^{-}$cells and a high activity of catechol 2,3dioxygenase in $\mathrm{TOL}^{+}$cells. A high level of expression probably also holds for other plasmid-encoded catabolic enzymes because all enzymes of the meta-pathway are expressed as part of a single regulon (see Assinder \& Williams, 1990). With high-copy-number plasmids in Escherichia coli (e.g. Seo \& Bailey, 1985; Bentley et al., 
1990) a similar relationship was found between the growth rate, the induction level of plasmid-encoded enzymes and the growth-rate advantage of segregants.

Different views exist on the dominant factors behind the burden that a plasmid imposes on its host. Lee \& Bailey (1984) emphasized the importance of the growth inhibitory effect as a consequence of competition for RNA polymerase between chromosomal and plasmid DNA. Bentley et al. (1990) concluded from the results of their experiments with pBR329 in E. coli RR1 that the level of synthesis of plasmid-encoded protein itself determines the extent of growth retardation. They also demonstrated that the effect of plasmid replication on cell growth is negligible.

It is difficult to identify the dominant factors in the growth-rate-retarding effect of the presence of TOL plasmid pWW0. During the chemostat experiments described in this study we never found any difference in growth yield on succinate between $\mathrm{TOL}^{+}$cells and $\mathrm{TOL}^{-}$ cells (results not shown). Furthermore, not enough data are available to estimate the contribution of plasmidencoded proteins to the total amount of proteins and the energy costs related therewith. Other factors, however, may be more decisive for the outcome of competition between $\mathrm{TOL}^{+}$cells and $\mathrm{TOL}^{-}$cells. For instance, a difference in affinity for the limiting nutrient might be caused by a difference in cell size. Electron microscopy studies indicate that wild-type cells of $P$. putida MT84 harbouring TOL plasmid pWW84 are significantly bigger than cells from a plasmid-free derivative strain (L. K. Chatfield, personal communication). A small cell size, and so a relatively high surface-to-volume ratio, may give a growth-rate advantage that is particularly high at very low concentrations of limiting substrates (Kuenen et al., 1977).

The discovery of mutants harbouring partially deleted plasmids instead of plasmid-free mutants gives rise to speculation about additional plasmid-encoded functions that could be advantageous under the given conditions. For instance, Bradley \& Williams (1982) found that the TOL plasmid also encodes for cell-surface-linked functions, such as pili. The structure of the cell surface may also be of importance for the uptake of nutrients at limiting concentration.

Our results may have some significance in explaining the slow biodegradation of certain xenobiotics in natural environments. The experiments indicate that the presence of a complex catabolic pathway, such as is encoded by TOL plasmids, may be a severe burden for the host under conditions that are strongly growth-limiting. The proliferation of strains harbouring catabolic plasmids may be limited if the benefits of the extra carbon and energy gain are not sufficient to compensate for this burden. Further quantitative research is required on this subject.
We thank J. C. H. van Eijkeren for assistance with the mathematical analysis.

\section{References}

Assinder, S. J. \& Williams, P. A. (1990). The TOL plasmids: determinants of the catabolism of toluene and the xylenes. Advances in Microbial Physiology 31, 1-70.

Bentley, W. E., Mirjalili, N., Andersen, D. C., Davis, R. H. \& Kompala, D. S. (1990). Plasmid-encoded protein: the principal factor in the "metabolic burden" associated with recombinant bacteria. Biotechnology and Bioengineering 35, 668-681.

Bradley, D. E. \& Williams, P. A. (1982). The TOL plasmid is naturally derepressed for transfer. Journal of General Microbiology 128, 3019-3024.

Chew, L. C. K., Tacon, W. C. A. \& Cole, J. A. (1988). Effect of growth conditions on the rate of loss of the plasmid pAT153 from continuous cultures of Escherichia coli HB101. FEMS Microbiology Letters 56, 101-104.

Duetz, W. A., Winston, M., van Andel, J. G. \& Williams, P. A. (1991). Mathematical analysis of catabolic function loss in a population of Pseudomonas putida $\mathrm{mt}-2$ during non-limited growth on benzoate. Journal of General Microbiology 137, 1363-1368.

Evans, C. G. T., Herbert, D. \& Tempest, D. W. (1970). The continuous cultivation of microorganisms. 2. Construction of a chemostat. Methods in Microbiology 2, 277-327.

Godwin, D. \& Slater, J. H. (1979). The influence of the growth environment on the stability of a drug resistance plasmid in Escherichia coli K12. Journal of General Microbiology 111, 201-210.

Keshavarz, T., Lilly, M. D. \& Clarke, P. H. (1985). Stability of a catabolic plasmid in continuous culture. Journal of General Microbiology 131, 1193-1203.

Kuenen, J. G., Boonstra, J., Schroder, H. G. J. \& Veldkamp, H. (1977). Competition for inorganic substrates among chemoorganotrophic and chemolithotrophic bacteria. Microbial Ecology 3, $119-130$.

LeE, S. B. \& Bailey, J. E. (1984). Analysis of growth rate effects on productivity of recombinant Escherichia coli populations using molecular mechanism models. Biotechnology and Bioengineering 26, 66-73.

Melling, J., Ellwood, D. C. \& Robinson, A. (1977). Survival of Rfactor carrying Escherichia coli in mixed cultures in the chemostat. FEMS Microbiology Letters 2, 87-89.

Meulien, P., Downing, R. G. \& Broda, P. (1981). Excision of the $40 \mathrm{~kb}$ segment of the TOL plasmid from Pseudomonas putida $\mathrm{mt}-2$ involves direct repeats. Molecular and General Genetics 184, 97-101.

Sala-Trepat, J-M. \& Evans, W. C. (1971). The meta cleavage of catechol by Azotobacter species: 4-oxalocrotonate pathway. European Journal of Biochemistry 20, 400-413.

SAYLeR, G. S., HoOper, S. W., LAYTON, A. C. \& King, J. M. H. (1990). Catabolic plasmids of environmental and ecological significance. Microbial Ecology 19, 1-20.

SEO, J. H. \& BaILEY, J. E. (1985). Effect of recombinant plasmid content on growth properties and cloned gene product formation in Escherichia coli. Biotechnology and Bioengineering 27, 1668-1674.

StePHENS, G. M. \& Dalton, H. (1988). Kinetics of benzoate-induced loss of the TOL plasmid from Pseudomonas putida MT15 during growth in chemostat culture. FEMS Microbiology Letters 55, 175-180.

Williams, P. A., Taylor, S. D. \& Gibb, L. E. (1988). Loss of the toluene-xylene catabolic genes of TOL plasmid pWW0 during growth of Pseudomonas putida on benzoate is due to a selective growth advantage of 'cured' segregants. Journal of General Microbiology 134, 2039-2048.

Wouters, J. T. M., Driehuis, F. L., Polaczek, P. J., van Oppenraay, M. H. A. \& VAN ANDEL, J. G. (1980). Persistence of the pBR322 plasmid in Escherichia coli $\mathrm{K} 12$ grown in chemostat cultures. Antonie van Leeuwenhoek 46, 353-362. 